\title{
Schedulling activity untuk meningkatkan aktivitas sehari-hari penderita skizofrenia
}

$\Phi$ PROCEDIA Studi Kasus dan Intervensi Psikologi p-ISSN 2302-1462; e-ISSN 2722-7669 ejournal.umm.ac.id/index.php/procedia 2021, Vol 9(3):100-106

DOI:10.22219/procedia.v9i3.16458

(C) The Author(s) 2021

()(1) 4.0 International license

\author{
Muthia Maharani ${ }^{1}$
}

\begin{abstract}
People with schizophrenia bring up positive and negative symptoms, among these symptoms cause sufferers to have no interest in one particular activity. This study aims to increase the activity of people with schizophrenia. The assessment methods used are interviews, observation, Wechsler Adult Intelligence Scale (WAIS), Thematic Apperception Test (TAT), Graphics and Wartegg Test. To deal with these problems, Scheduling Activity Method is used. The results obtained are the subject's activity in leisure time increases so that daydreaming and hallucinating activities are reduced.
\end{abstract}

\section{Keywords}

Negative symptoms, schizophrenia, scheduling activity, daily activity

\section{Pendahuluan}

Skizofrenia merupakan gangguan psikotik yang ditandai dengan gangguan dalam fungsi pikiran, emosi, dan perilaku (Davison, 2006). Gejala lain yang muncul seperti penarikan diri dari sosial, perilaku yang tidak biasa dalam berbicara, berpikir, ataupun perilaku sehari-hari, yang mungkin mendahului atau terlihat bersamaan dengan gangguan kejiwaan lainnya. Pada kebanyakan kasus terjadi penurunan yang perlahan dan lebih dalam fungsi individu.

Terjadinya kemunduran fungsi individu mungkin saja memerlukan waktu bertahun-tahun. Fase kemunduran ini disebut dengan fase predormonal. Hal ini ditandai dengan berkurangnya minat dalam aktivitas sosial dan meningkatnya kesulitan dalam memenuhi tanggung jawab seharihari. Setelah mengalami kemunduran yang terus menerus, maka semakin lama terjadi perubahan kepribadian yang diawali dari perubahan pembicaraan yang melantur yang berangsur-angsur berubah hingga berjalan tanpa arah, mengumpulkan sampah dan menimbun makanan yang biasa disebut fase akut. Setelah mengalami fase akut, individu masuk pada fase residual yaitu perilaku kembali pada tingkat sebelumnya yang menjadi ciri fase prodormonal (Nevid et al., 2005). Ada lima domain fitur kunci skizofrenia dan gangguan psikotik dalam Diagnostic And Statistical Manual of Mental Disorders (DSM V).

Delusi secara umum diartikan sebagai pikiran atau pandangan yang tidak berdasar (tidak rasional), biasanya berwujud sifat kemegahan diri atau perasaan dikejar-kejar, pendapat yang tidak berdasarkan kenyataan atau khayal. Dalam DSM dijelaskan bahwa delusi adalah keyakinan yang menentap yang tidak menerima untuk berubah pada kejadian yang terjadi serta mungkin terdiri dari beberapa macam seperti berikut: (1) Persecutory delusions seperti keyakinan pada kejahatan, godaan, dan seterusnya dilakukan oleh individu, organisasi, atau kelompok lain; (2) Referential delusions seperti keyakinan pada gesture tertentu, komentar, isyarat lingkungan dan dilakukan oleh orang tersebut langsung; (3) Grandiose delusions terjadi ketika keyakinan individu bahwa dia memiliki kemampuan 'luar biasa', kekayaan, dan popularitas; (4) Erotomanie delusions terjadi ketika keyakinan individu yang salah bahwa orang lain jatuh cinta padanya; (5) Nihilistic delusions termasuk pendirian yang kuat bahwa malapetaka akan terjadi; dan (6) Somatic delusions fokus mengenai kesehatan dan fungsi organ yang belum diperoleh (mengenai badan dan jasad).

Halusinasi. Halusinasi secara umum diartikan sebagai pengalaman indra tanpa adanya perangsang pada alat indra yang bersangkutan, misal mendengar suara tanpa ada sumber suara tersebut. Halusinasi pada DSM V diartikan sebagai persepsi seperti pengalaman yang terjadi tanpa stimulus eksternal. Hal tersebut hidup dan jelas dengan usaha penuh dan memilik efek yang sama seperti persepsi normal, dan tidak berada dibawah kontrol. Hal ini terjadi pada modalitas sensori tapi halusinasi auditori adalah hal yang paling sering terjadi.

Kemampuan berpikir dan bericara yang tidak terorganisir. Fitur ini secara umum menjelaskan kemampuan

${ }^{1}$ Biro Psikologi Antara, Kab.Tulungagung

Korespondensi:

Muthia Maharani, Biro Psikologi Antara, RT 2 RW 2 Dusun Pelem Desa Pelem, Kecamatan Campurdarat Kabupaten Tulungagung Email: muthiasaajaa@gmail.com 
berpikir dan berbicara yang tidak utuh atau tidak menjadi satu kesatuan dari individu maupun lawan bicaranya serta berbicara secara melompat-lompat. DSM V menyatakan bahwa kemampuan berfikir yang tidak teroganisir diduga atau diambil berdasarkan dari cara berbicara individu. Jawaban dari pertanyaan dapat berbelok atau sedikit tidak berkesinambungan atau tidak berkesinambungan sama sekali. Penderita skizofrenia berbicara tidak terorganisasi dan tidak koheren dan menyerupai aphasia reseptif sebagai disorganisasi bahasa. Perilaku yang kacau atau campur aduk atau tidak bisa dibedakan (termasuk katatonia yaitu kelainan psikis yang disebabkan oleh ketegangan otot yang tidak wajar). Selain itu ada pula gejala negatif (negative symptoms) jumlah porsi susbstansial dan tidak sehat. Ada dua simptom negatif yang menjadi bagian dari skizofrenia yaitu diminished emotional expression dan avolition.

Diminished emotional expression termasuk reduksi pada ekspresi emosi pada wajah, kontak mata, intonasi perbicangan dan gerakan tangan, kepala, dan wajah normal yang menunjukan intonasi bicara. Avolition adalah penurunan motivasi dan kegiatan. Individu duduk dalam waktu yang lama dan menunjukkan sedikit ketertarikan pada kegiatan sosial. Gejala negatif lain yaitu alogia (mengurangi berbicara ke orang lain), anhedonia (berkurangnya kemampuan untuk mendapatkan pengalaman menyenangkan), asociality (ketiadaan ketertarikan interaksi social) dan diasosiasikan dengan avolition.

Perlunya aktivitas pada waktu luang penderita skizofrenia dapat membantu penderita memiliki kegiatan yang terarah dan bermanfaat. Kurangnya aktivitas di waktu luang, menjadikan penderita cenderung kurang aktif, dan memungkinkan untuk memperburuk kondisi karena gejalagejala yang ada semakin diperkuat. Kurangnya aktivitas akan membuat penderita skizofrenia semakin menarik diri dari lingkungan sosial, bahkan memunculkan waham atau halusinasi dengan lebih sering.

\section{Metode Asesmen}

Metode yang digunakan dalam asesmen adalah wawancara dan observasi disertai pemberian seperangkat alat tes. Wawancara diberikan pada subjek, karyawan yayasan subjek berada dan keluarga subjek untuk mengetahui keseharian dan riwayat kehidupan subjek. Observasi digunakan untuk mengetahui perilaku subjek selama tes, wawancara dan perilaku subjek dalam melaksanakan aktivitas harian, baik saat ada kegiatan maupun pada waktu luang. Selain itu juga observasi digunakan untuk mengetahui proses sosialisasi subjek. Seperangkat tes psikologi yang diberikan pada subjek adalah tes kepribadian dan tes kecerdasan. Tes kepribadian meliputi Thematic Apperception Test (TAT) untuk mengetahui need dan press, serta konflik yang dialami subjek. Tes grafis BAUM, Draw A Person (DAP), dan House Tree Person (HTP) untuk melihat kepribadian subjek yang meliputi dorongan-dorongan, serta Wartegg untuk melihat emosi, aktivitas dan fungsi intelektual yang digunakan subjek.
Sedangkan tes kecerdasan yang diberikan yaitu Wechsler Adult Intelligence Scale (WAIS) untuk melihat kapasitas intelektual dan kemunduran yang dialami subjek.

\section{Presentasi Kasus}

Subjek seorang wanita berusia 57 tahun, masuk ke yayasan Dian Atma Jaya sejak tahun 2014. Sebelumnya subjek pernah dirawat di RSJ Radjiman Wediodiningrat sebanyak empat kali, dan menjalankan pengobatan alternatif sebanyak tiga kali. Subjek adalah anak ke lima dari lima bersaudara. Subjek menderita skizofrenia sejak usia 18 tahun. Subjek datang dengan keluhan sering merasa diraba pada bagian punggung, sering berbicara sendiri, kehilangan minat, emosi dangkal dan sulit tidur. Subjek merasa sering diraba oleh seseorang dan membuat subjek gelisah. Subjek juga merasa akibat rabaan tersebut muncul rasa sakit seperti dagingnya lepas, kadang seperti disetrum dan digoyang-goyangkan, serta sering mendengar suara orang yang marah- marah, membentak dan berkata kasar.

Subjek selalu memegang punggung untuk menghilangkan rasa diraba seseorang tersebut. Menurut keterangan subjek rabaan terebut berasal dari mantan pacarnya yang dulu tinggal di kota yang sama. Setelah itu subjek juga menyatakan bahwa rabaan tersebut dilakukan oleh kakak iparnya yang tidak suka dengan dia tanpa diketahui penyebabnya. Hal tersebut muncul sudah lama sejak subjek belum menikah. Subjek telah menikah dan memiliki anak. Anak subjek sekarang telah berkeluarga. Sejak usia enam bulan anak subjek dititipkan pada saudaranya dan dirawat bersama.

Orang tua subjek bercerai saat usia subjek masih anakanak. Subjek dan kakak subjek yang ke empat diasuh oleh ibunya. Setelah perpisahan tersebut, subjek jarang berinteraksi dengan ayahnya. Subjek dan kakaknya yang ke empat tinggal bersama ibu subjek sedangkan ketiga saudaranya yang lain ikut paman subjek yang menjadi dokter. Peristiwa tersebut membuat subjek kehilangan figure ayah sejak usia anak-anak. Subjek hidup serba pas-pasan saat tinggal dengan ibu dan kakanya. Karena kondisi ekonomi yang terbatas, membuat subjek hanya mampu menyelesaikan pendidikan sampai tingkat SMP saja. Setelah ibu subjek meninggal, subjek dan saudaranya ikut tinggal bersama paman subjek dan ketiga saudaranya yang lain.

Paman subjek bekerja sebagai dokter dan memiliki sebuah klinik di kediamannya. Agar memiliki pekerjaan, subjek ikut bekerja di klinik milik pamannya tersebut. Subjek bekerja membantu administrasi keluar masuknya obat di apotik. Sedangkan pada saat itu, saudara subjek yang telah lama ikut pamannya dapat bekerja di tempat lain dan memiliki penghasilan yang lebih baik dari subjek. Hal tersebut memicu timbulnya rasa iri dalam diri subjek terhadap saudaranya, karena subjek merasa dari lima bersaudara, hanya subjek yang dijadikan pembantu, hanya disuruh-suruh dan merasa kakak subjek memiliki kehidupan yang lebih baik. Subjek dinilai sebagai 
seorang pesolek oleh saudaranya karena kegemaran subjek berdandan, merawat diri, memiliki rambut yang panjang dan mengutamakan penampilan. Hal tersebut didukung dengan fasilitas yang diberikan oleh paman subjek yang selalu tersedia apapun sehingga subjek terbiasa hidup enak. Subjek yang saat itu bekerja di apotik, ditawari obat untuk menurunkan berat badan yang mengandung amfetamin dengan dosis besar. Kilen yang merasa kegemukan mengkonsumsi obat tersebut. Selama mengkonsumsi obat tersebut tidak diimbangi dengan makan, minum dan istirahat yang cukup. Bahkan setelah efek obatnya hilang, subjek menyuntikkan sendiri obat tersebut ke tubuhnya. Kelebihan dosis dari obat tersebut, menjadikan subjek mengalami kerusakan syaraf sehingga perilaku subjek seringkali marah tanpa kendali, gelisah dan sering melamun.

Subjek pada saat itu memiliki pacar dan telah berencana menikah. Karena mengetahui kondisi subjek yang sering gelisah, mudah marah tanpa kendali dan sering melamun, pacar subjek membatalkan perikahan dan menikah dengan wanita lain. Kejadian tersebut membuat subjek histeris, mudah marah, merasa sangat kehilangan, sering melamun dan muncul perilaku baru berupa suka menulis surat cinta. Kegiatan menulis tersebut bahkan bisa berlangsung seharian dan menghabiskan berlembar-lembar kertas untuk menulis dalam satu hari. Peristiwa tersebut menjadi pencetus munculnya perilaku subjek yang tidak dapat dikendalikan. Akhirnya subjek dibawa ke RSJ oleh pihak keluarga untuk mendapatkan pertolongan dan disarankan oleh pihak RSJ untuk menikahkan subjek. Atas persetujuan dari keluarga, subjek kemudian dinikahkan dengan seorang pemuda dari luar kota.

Saat hidup berumah tangga, kehidupan subjek banyak dibantu keluarga. Gejala-gejala yang dialami subjek seperti mudah marah, gelisah juga sering kambuh namun keluarga masih bisa mengatasi kekambuhan tersebut. Hal tersebut dipicu oleh perbedaan kondisi pada saat subjek remaja dan setelah menikah. Klein yang terbiasa hidup serba ada dan tercukupi tidak dapat beradaptasi dengan kehidupan yang baru dimana subjek harus berusaha mencukupi kebutuhannya. Hal tersebut memicu kecemasan subjek karena tidak dapat terpenuhi kebutuhannya, seperti pada saat stok beras di rumah tinggal setengah subjek langsung berbelanja dan mengisi tempat tersebut hingga penuh. Pernah suatu kali subjek mengamuk dan membuang peralatan dapur yang ada di rumahnya. Pada saat itu diketahui bahwa subjek sedang hamil empat bulan. Setelah melahirkan, subjek dipisahkan dengan anaknya karena kekhawatiran keluarga pada subjek tidak dapat mengruus anaknya. Namun karena kasihan dengan bayi subjek yang terus menangis, akhirnya bayi tersebut dipertemukan kembali dengan subjek dan keluarga mengijinkan subjek untuk merawat anaknya. Kecemasan yang berlebih muncul kembali setelah subjek tinggal dengan bayinya. Pada saat bayi subjek berusia tujuh bulan subjek mulai sering gelisah, mudah marah dengan alasan tidak dapat mencukupi kebutuhan anaknya. Subjek mulai menghitung kebutuhan anaknya untuk sekolah mulai dari biaya masuk, SPP hingga kebutuhan yang lain, padahal saat itu anak subjek masih berusia tujuh bulan. Beban hidup yang bertambah membuat kondisi subjek lebih sering kambuh dan tidak dapat diatasi oleh keluarga hingga subjek dibawa ke pengobatan alternatif. Namun, bukannya membaik kondisi subjek semakin memburuk, nampak tidak terawat, sangat kurus dan muncul halusinasi.

Subjek dirawat bergantian oleh ke empat saudaranya, satu tahun ikut saudara pertama dan tahun berikutnya ikut saudara yang lain. Pada saat subjek tinggal dengan kakaknya yang ke dua, terjadi pengalaman traumatis yang berulang-ulang. Suami kakak subjek memiliki karakter yang keras, sangat disiplin dan bekerja sebagai sopir. Pernah suatu hari subjek sedang di kamar mandi dan mulai melamun. Karena kakak ipar subjek sedang terburuburu bekerja, akhirnya kakak ipar subjek yang tidak sabar dan sudah terdesak waktu mendobrak pintu dan meneriaki subjek yang sedang berada di kamar mandi. Kejadian tersebut sering terjadi dimana subjek mendapat marah dari kakak iparnya karena subjek seringkali melamun saat di kamar mandi. Dari peristiwa tersebut, muncul waham subjek bahwa kakak ipar subjek sering mengganggu subjek, menyakiti punggung subjek dan memarahi subjek. Selain itu juga muncul ketakutan subjek ketika melihat dan mendengar orang marah dan berkata kasar.

Subjek memiliki IQ 67 yang termasuk dalam kategori borderline. Selain itu, subjek juga mengalami kemunduran kognitif dimana didapati skor MD i $20=27,24 \%$. Subjek merupakan individu yang cukup tertutup dengan lingkungannya. Subjek memiliki kepribadian yang cenderung kaku, dan memiliki dorongan yang besar. Subjek kurang mampu beradaptasi dengan baik di lingkungannya. Subjek juga memiliki kecemasan dan ketakutan yang cenderung tinggi. Dalam bersosialisasi subjek kurang dapat membaur dengan lingkungannya. Dalam penyelesaian masalah subjek cenderung pasif tidak melakukan apa-apa. Subjek juga kurang dapat mengekspresikan emosi terhadap lingkungannya.

Model diathesis stress menjelaskan pada individu dengan kerentanan psikologis apabila berinteraksi dengan tekanan-tekanan yang melebihi ambang batas, maka individu tersebut akan mengalami gangguan (Davison, 2006). Lingkungan yang terlalu menuntut, tidak mempertimbangkan perasaan, tidak memberikan penghargaan serta mengabaikan diyakini memberikan sumbangan besar terhadap terjadinya gangguan. Memiliki diathesis atau bawaan pada suatu gangguan akan meningkatkan resiko seseorang untuk mengalami gangguan tersebut. Menurut Linehan (Davison, 2006) gangguan kepribadian dapat terjadi apabila seseorang memiliki diathesis biologis berupa kesulitan mengendalikan emosi dan dibesarkan dalam lingkungan keluarga yang menginvalidasi. Lingkungan yang memvalidasi adalah lingkungan dimana keinginan dan perasaan seseorang tidak dipertimbangkan dan tidak dihargai sehingga disregulasi emosional inilah yang memicu munculnya gangguan kepribadian. 
Subjek yang pada dasarnya memiliki kebiasaan utuk hidup serba kecukupan dan terbiasa dimanja, pada akhirnya membuat subjek memiliki kecemasan yang sangat besar jika kebutuhannya tidak dapat dipenuhi sehingga seringkali subjek menjadi marah-marah dan menyalahkan diri sendiri. Dari peristiwa tersebut yang muncul berulang, muncul gejala awal yaitu sering menyalahkan diri, mengamuk, dan sering melamun. Gejala yang sering muncul, membuat keluarga membawa subjek ke pengobatan alternative di luar kota selama satu tahun. Setelah satu tahun, tanpa ada dukungan keluarga yang sering menjenguk, subjek pulang dalam keadaan semakin parah. Subjek mengalami halusinasi seperti ada orang yang marah-marah dan keadaan subjek lebih sering mengamuk sehingga subjek didiagnosa skizofrenia.

Pada kasus ini, perilaku subjek selama berada di yayasan disamakan dengan perilaku pada saat berada di lingkungan pamannya dimana semua kebutuhan tercukupi dengan baik. Misalnya, saat mandi subjek selalu menunggu hingga baik air penuh sehingga memakan waktu yang cukup lama di dalam kamar mandi. Selain itu, ketika banyak waktu luang, subjek selalu duduk di lantai dan berdiam diri karena dengan duduk di lantai subjek merasa lebih nyaman dan sejuk seperti pada saat berada di rumah pamannya. Subjek menjadi pasif dan sering memunculkan halusinasi ketika tidak ada aktivitas di waktu luang yang diberikan. Tidak adanya aktivitas dan orang yang mengawasi subjek, membuat subjek semakin sering menjadi pasif ketika tidak ada kegiatan.

Berdasarkan pendekatan behavioral perilaku terbentuk dengan adanya pengkondisian. Perilaku muncul karena adanya stimulus yang dikondisikan (Alwisol, 2011). Stimulus awal pada subjek adalah adanya waktu luang pada pukul 08.00 - 11.00, dan pukul 16.00 - 17.00 digunakan subjek untuk duduk menyendiri, melamun dan memunculkan halusinasi. Stimulus tersebut dikondisikan dengan tidak diberikan aktivitas apapun saat waktu luang, dan tidak diberikan penguatan positif terhadap aktivitas yang dilakukan subjek. Sehingga respon yang dikondisikan adalah subjek tidak memiliki motivasi untuk beraktivitas sehingga subjek hanya diam ketika tidak ada aktivitas yang dilakukan baik saat waktu luang maupun disela-sela waktu pada saat jeda aktivitas.

Untuk meningkatkan aktivitas pada subjek, maka diperlukan sebuah penanganan agar subjek lebih banyak beraktivitas di waktu luang. Penangan yang diberikan difokuskan pada perilaku pasif, sehingga kemunculan halusinasi dapat dikurangi. Adapun terapi yang digunakan adalah terapi scheduling activity yaitu berupa pemberian jadwal aktivitas untuk subjek dalam satu hari dimana setiap waktu luang juga diisi dengan aktivitas yang menyenangkan dan membuat subjek lebih aktif.

\section{Diagnosis dan Prognosis}

Berdasarkan hasil asesmen dan referensi dari DSM V, diagnosis untuk subjek MH adalah Skizofrenia (F20.9)
295.90. Diagnosis tersebut berdasarkan dua atau lebih gejala yang muncul yaitu delusi (merasa dirinya adalah seseorang yang rendah diri, pemalu, dan orang lain akan mengganggu) dan halusinasi (mendengar bisikan-bisikan seperti orang marah, dan merasa ada yang meraba di bagian punggung). Perkataan atau bahasa subjek tidak terorganisir, serta kegagalan untuk meraih level yang diharapkan dalam hubungan interpersonal, akademik, dan fungsi pekerjaan. Gejala yang dialami berlangsung selama setidaknya 6 bulan, dan di dalam periode 6 bulan setidaknya simptom muncul selama 1 bulan serta tidak berkaitan dengan penyalahgunaan NAPZA (bukan efek dari drug abuse).

\section{Prognosis}

Prognosis subjek dalam menjalankan aktivitas ini adalah sedang. Prognosis sedang dipengaruhi adanya faktor positif dan negatif. Dari faktor positif, subjek memiliki komitmen yang baik untuk melaksanakan aktivitas, subjek juga cukup kooperatif dalam berkomunikasi dan memberikan informasi kepada terapis. Subjek juga cukup baik dalam menerima dan memahami kalimat perintah saat memberikan tugas kepada subjek. Faktor negatif diantaranya perlunya dukungan sosial dan pengawasan dari orang lain agar subjek melakukan aktivtas sesuai dengan jadwal. Selain itu subjek memiliki kecemasan bahwa teman yang lain akan menggangu aktivitasnya apabila tidak didampingi oleh orang lain, sehingga dalam melaksanakan terapi ini diperlukan pendampingan dari orang lain.

\section{Intervensi}

Target intervensi adalah untuk meningkatkan aktivitas penderita skizofrenia. Penanganan ini fokus pada aktivitas yang dilakukan subjek, dengan aktivitas yang menyenangkan sehingga subjek tetap aktif dan gejala negatif dapat berkurang. Salah satu bentuk terapi yang dapat diberikan kepada penderita skizofrenia adalah terapi scheduling activity. Scheduling activity merupakan salah satu teknik dalam terapi perilaku.

Berdasarkan pendekatan behavior, perilaku terbentuk karena adanya penguatan positif. Penguatan positif tersebut membuat individu termotivasi untuk memunculkan kembali perilaku yang diharapkan. Terapi scheduling activity merupakan salah satu bentuk terapi yang bertujuan untuk membuat rencana aktivitas subjek dan memonitoring aktivitas yang menyenangkan bagi subjek. Selain itu, pemberian scheduling activity ini bertujuan untuk mengurangi perilaku pasif yang cenderung membuat subjek semakin sering memunculkan halusinasi. Scheduling activity membantu subjek untuk memonitoring aktivitas mereka dan membuat subjek lebih sadar tentang aktivitas menyenangkan yang mereka pilih. Hal ini juga membuat mereka lebih cermat dalam menyiapkan kegiatan yang lebih bermakna dan menyenangkan sehingga dapat 
mengurangi gejala dari gangguan yang dialami. Bagi terapis dengan pemberian terapi ini juga dapat mengidentifikasi aktivitas yang memuculkan distress subjek dan yang menyenangkan bagi subjek (Winterwood et al., 2003).

Target terapi scheduling activity adalah subjek mampu menjadi lebih aktif terutama pada waktu luang sehingga kemungkinan munculnya halusinasi berkurang. Terapi berupa pemberian jadwal aktivitas menyenangkan yang disusun bersama subjek. Pemberian jadwal bertujuan agar subjek selalu memiliki aktivitas untuk dilakukan pada waktu luang. Waktu luang yang biasanya hanya digunakan untuk duduk dan memunculkan halusinasi diisi kegiatan yang menyenangkan menurut subjek. Kegiatan yang menyenangkan membuat subjek termotivasi untuk melakukan aktivtias dan menjadi lebih aktif.

Sebelum diberikan pilihan mengenai aktivitas menyenangkan, terlebih dahulu dilakukan monitoring tentang aktivitas sehari-hari subjek. Monitoring ini bertujuan untuk mengidentifikasi aktivitas apa yang dilakukan subjek dalam satu hari (Wenzel et al., 2011). Beberapa jenis aktivitas diidentifikasi dan subjek memberikan penilaian mana yang paling mudah dan menyenangkan untuk dikerjakan (Winterwood et al., 2003). Aktivitas yang diberikan berupa membuat kerajinan tangan. Aktivitas membuat kerajinan tangan diberikan pada waktu luang subjek di pagi dan malam pada hari selasa dan kamis pada saat ada kegaitan malam. Berikut adalah rancangan terapi scheduling activity pada subjek:

Sesi I: Terapis memberikan informed consent kepada subjek. Terapis juga memberitahu subjek tentang prosedur kegiatan yang akan dilakukan. Terapis menanyakan kepada subjek tentang kesiapan dan kesediaan subjek untuk melakukan aktivitas yang akan dilakukan. Terapis menjelaskan kepada subjek tujuan dari kegiatan yang akan dilakukan. Subjek diarahkan untuk mengungkapkan harapan yang ingin dicapai pada kegiatan terapi yang akan dilakukan. Keseluruhan proses terapi bertujuan untuk membuat subjek menjadi lebih aktif dan mengurangi perilaku pasif yang muncul selama di yayasan. Selanjutnya subjek diarahkan untuk lebih termotivasi mengikuti seluruh rangkaian terapi dan membuat komitmen untuk melaksanakan seluruh prosedur terapi hingga selesai.

Langkah ini dilakukan dengan mengarahkan subjek menyatakan hal-hal yang membuat subjek bersemangat serta adanya dukungan dari karyawan yayasan pada subjek. Salah satu yang memotivasi subjek adalah keinginan untuk pulang dan kembali sehat. Subjek menyatakan kesanggupan dalam menjalankan kegiatan bersama terapis. Ketika menyatakan kesediaan, subjek tidak memberikan ekspresi apapun. Ketika dijelaskan tentang tujuan dari kegiatan terapi, subjek menyetujui tujuan tersebut dengan alasan bahwa dengan menurut pada terapis akan membantu subjek menjadi lebih baik selama di yayasan, sehingga subjek cepat pulang. Selain itu subjek juga memberikan pertanyaan kepada terapis terkait berapa lama kegiatan akan berlangsung.
Sesi I: Terapis mengidentifikasi aktivitas harian subjek yang dilakukan secara rutin. Terapis mengidentifikasi waktu luang subjek baik secara durasi dan frekuensinya dalam satu hari. Terapis mengidentifikasi apa yang dirasakan subjek serta kendala yang dihadapi dalam beraktivitas. Terapis bersama subjek mengidentifikasi aktifitas yang telah dilakukan subjek sepanjang hari di yayasan. Terapis bersama subjek juga mengidentifikasi kapan saja waktu luang muncul dalam satu hari serta berapa lama waktu luang tersebut berlangsung. Subjek menceritakan aktivitas harian yang dilakukan dengan nada datar, dan nampak kurang termotivasi.

Ketika ditanya tentang perasaan subjek saat melaksanakan aktivitas tersebut, subjek menyatakan bahwa aktivitas tersebut merupakan aktivitas yang biasa saja dilakukan. Dalam melaksanakan aktivitas rutin tidak ada kendala yang dirasakan oleh subjek. Namun ketika terapis menanyakan kepada subjek apabila diberikan tanggung jawab berupa PR untuk dikerjakan saat malam hari, berupa diberikan buku untuk dibaca subjek mengatakan tidak dapat menyimpan buku tersebut, karena takut akan diambil oleh temannya

Sesi III: Terapis dan subjek bersama-sama memutuskan aktivitas untuk mengisi waktu luang subjek. Terapis menanyakan pada subjek apakah subjek memiliki kegemaran dalam aktivitas tertentu. Terapis menawarkan kepada subjek untuk membuat kerajinan tangan, dimana tugas subjek adalah menjahit atau mengelem saja. Terapis bersama subjek membuat jadwal yang akan dilakukan dalam mengisi waktu luang. Subjek menyatakan tidak ada aktivitas yang disukai, subjek menyatakan bahwa semua aktivitas sama saja. Apabila diajak untuk melakukan sesuatu subjek mengikuti perintah dan mengerjakannya.

Subjek nampak antusias dan bertanya kerajinan apa yang akan dibuat. Kemudian terapis menjelaskan kerajinan yang akan dibuat. Subjek bertanya beberapa kali tentang bagaimana cara membuat kerajinan tangan tersebut, apa bentuknya, dari apa bahannya serta apa yang akan dilakukan subjek. Subjek menyatakan kesediaannya untuk melakukan aktivitas tersebut. Terapis dan subjek mendiskusikan reward yang akan didapat oleh subjek ketika pelaksanaan aktivitas berjalan dengan baik. Reward berupa hal yang disukai oleh subjek yaitu berupa barang.

Sesi IV: Terapis memberikan jadwal tertulis yang berisi kegiatan subjek dalam satu hari. Terapis mengajak subjek untuk membaca jadwal tersebut dan memberikan pertanyaan kepada subjek tentang kegiatan pada jadwal tersebut. Terapis memberikan contoh cara membuat kerajinan tangan. Terapis memberikan pujian serta dorongan kepada subjek untuk melanjutkan kegiatan. Subjek membaca dengan cermat jadwal yang diberikan. Subjek mampu menjawab dengan benar pertanyaan dari terapis. Subjek melaksanakan aktivitas sesuai dengan jadwal yang telah diberikan. Pada pukul 08.00-10.00 subjek beraktivitas membuat kerajinan tangan. Setelah itu pada pukul 10.00-11.00 subjek meminta ijin ke belakang 
untuk mengangkat dan melipat baju yang dijemur serta membantu menyiapkan makan siang.

Sesi V: Terapis juga menanyakan kepada subjek kesiapan untuk melanjutkan aktivitas pada hari sebelumnya. Pada hari kedua, subjek diberikan pertanyaan terlebih dahulu mengenai aktivitas yang dilakukan pada pagi hari. Terapis memberikan hasil pekerjaan pada hari sebelumnya kepada subjek, dan memberikan motivasi untuk melanjutkan pekerjaan tersebut. Subjek menyatakan bangun pagi hari pada pukul 02.00 pagi dan kemudian mandi, yang dilanjutkan dengan membantu petugas meyiapkan sarapan. Kemudian subjek sarapan pada pukul 07.00-08.00 pagi. Subjek bertanya kepada terapis apakah hari ini akan melanjutkan kegiatan membuat kerajinan tangan berupa menjahit. Setelah itu subjek juga mulai duduk di kursi, dan berada di ruang tamu pada saat membuat kerajinan tangan.

Sesi VI: Terapis memberi pertanyaan kepada subjek seputar jadwal yang diberikan kepada subjek. Terapis memberikan satu contoh hasil kerajinan tangan yang sudah jadi kepada subjek yang dijadikan sebagai reward kepada subjek. Terapis memotivasi subjek untuk melanjutkan aktivitas membuat kerajinan tangan. Terapis mengidentifikasi perasaan subjek selama membuat kerajinan tangan. Subjek menjawab pertanyaan terapis bahwa pada pukul 08.00 hingga 10.00 subjek akan membuat kerajinan tangan dengan terapis. Subjek tersenyum ketika diberikan contoh hasil kerajinan tangan yang sudah jadi, namun subjek tidak berani membawa kerajinan tangan yang diberikan karena takut akan diambil teman yang lain.

Ketika waktu mendekati jam makan siang, terapis menawarkan kepada subjek untuk istirahat, namun subjek menyatakan bahwa pekerjaan yang dilakukan kurang sedikit sehingga subjek menyelesaikan terlebih dahulu tugas yang diberikan. Subjek selalu membawa jadwal yang diberikan. Subjek juga dapat menjawab pertanyaan terapis tentang aktivitas yang dilakukan. Subjek melaksanakan kegiatan sesuai dengan jadwal yang diberikan, pada pagi hingga sore hari.

Sesi VII: Terapis menanyakan kepada subjek tentang jadwal kegiatan yang diberikan. Terapis mengajak subjek membuat bentuk kerajinan tangan yang lain. Terapis memberikan contoh kepada subjek bentuk pembuatan kerajinan tangan yang lain. Terapis mengajak subjek untuk menjahit dan memasukkan dakron pada perca yang dijahit kecil untuk dijadikan bros. Terapis memberikan motivasi kepada subjek dan reward berupa pujian.

Subjek mulai memiliki inisiatif untuk melaksanakan aktivitas tanpa melihat jadwal terlebih dahulu. Pada saat pelaksanaan subjek lebih banyak fokus pada pekerjaan yang dilakukan yaitu melipat kain dan menjahit. Subjek meletakkan barang yang dijadikan bahan membuat kerajinan tangan di dekat subjek, dan mengatakan aktivitas yang dilakukan ketika ada teman subjek yang menanyakan aktivitas subjek.
Sesi VIII: Terapis menanyakan kepada subjek tentang jadwal kegiatan yang diberikan. Terapis mengajak subjek membuat bentuk kerajinan tangan yang lain. Terapis memberikan contoh kepada subjek bentuk pembuatan kerajinan tangan yang lain. Terapis mengajak subjek untuk menjahit dan memasukkan dakron pada perca yang dijahit kecil untuk dijadikan bros. Terapis memberikan motivasi kepada subjek dan reward berupa pujian. Subjek langsung mengerjakan aktivitas membuat kerajinan tangan tanpa diberikan instruksi terlebih dahulu. Subjek juga memiliki inisitaif untuk melaksanakan aktivitas berikutnya dan meminta ijin pada terapis. Subjek nampak sesekali tersenyum ketika diberikan pujian atas hasil pekerjaan yang telah diberikan.

\section{Sesi IX dan X: terapis memberikan bahan dan alat untuk} membuat kerajinan tangan. Terapis memantau aktivitas subjek sepanjang hari. Terapis mengobservasi pelaksanaan aktivitas pada waktu luang yang dilakukan subjek. Terapis memberikan bahan berupa kertas dan lem, dan mengajari subjek untuk melipat kertas tersebut dan menjadikan bahan tersebut menjadi tugas rumah. Subjek melaksanakan aktivitas dengan tekun dan menyelesaikan tugas yang diberikan tanpa diberikan contoh oleh terapis terlebih dahulu. Pada akhir sesi subjek menyatakan bahwa subjek merasa senang diajari membuat kerajinan tangan, dan mau apabila diajari membuat kerajinan tangan yang lain. Subjek juga memahami bahwa tugas rumah yang diberikan adalah tanggung jawab subjek. Subjek menyatakan kepada terapis bahwa tugas rumah tersebut disimpan, dan akan dititpkan pada petugas pada malam hari agar tidak diambil oleh teman subjek.

\section{Hasil dan Pembahasan}

\section{Hasil}

Berdasarkan hasil intervensi, nampak terjadi perubahan pada perilaku subjek. Perubahan yang muncul diantaranya adalah perilaku subjek yang lebih aktif, memiliki inisiatif untuk melaksanakan aktivitas pada waktu luang. Aktivitas yang dilakukan berdasarkan inisiatif subjek adalah subjek langsung meminta untuk menyelesaikan tugas sebelumnya tanpa harus diberikan perintah terlebih dahulu.

Pada sesi 8 , subjek juga melakukan aktivitas menonton televisi pada waktu luang di sore hari sambil menunggu waktu makan sore. Subjek juga menjadi lebih terbuka dan bersosialisasi dengan teman- teman di yayasan walaupun dengan wujud yang sangat minim sekali seperti menjelaskan aktivitasnya, menjelaskan alat dan bahan yang dipakai. Perilaku lain yang nampak adalah komitmen subjek untuk menyelesaikan tugas dengan baik. Subjek menyelesaikan tugas terlebih dahulu baru beralih pada aktifitas yang lain. Pada akhir sesi, perubahan yang nampak pada subjek adalah subjek mampu mengekspresikan perasaannya terhadap kegiatan yang diberikan. 


\section{Pembahasan}

Terapi yang diberikan kepada subjek telah berhasil meningkatkan aktivitas waktu luang subjek. Keberhasilan tersebut ditunjang oleh adanya motivasi subjek yang kuat untuk mengikuti kegiatan. Pada kasus subjek, subjek termotivasi mengikuti keseluruhan kegiatan untuk menunjang kesembuhan. Motivasi yang kuat untuk mengikuti kegiatan ditandai dengan sikap subjek yang cukup kooperatif. Subjek menyetujui seluruh kegiatan yang diberikan. Apabila ada kesulitan maupun kendala dalam menjalankan aktivitas subjek akan bertanya kepada terapis. Selain itu, bentuk aktivitas tambahan yang diberikan pada waktu luang merupakan aktivitas yang membuat subjek senang, serta membuat subjek merasa bangga dengan hasil dari kerajinan tangan yang telah dibuat. Namun, dalam menjalankan kegiatan tersebut perlu pegawasan dari pihak lain. Untuk melakukan aktivitas yang berhubungan dengan keterampilan, subjek memerlukan pendampingan dari orang lain. Ketika aktivitas tersebut dilakukan tanpa pengawasan, subjek menyembunyikan barang-barang karena menurutnya akan diambil oleh pasien yang lain. Selain itu, tanpa adanya pengawasan subjek akan kembali terdiam dan duduk tanpa melakukan aktivitas apapun. Walaupun pada akhirnya subjek mau mengisi waktu luang dengan menonton televisi maupun mengobrol, namun aktivitas tersebut tidak dilakukan dalam waktu yang lama dan subjek kembali duduk melamun. Sedangkan dari dukungan sosial, minimnya pengawasan membuat subjek menjadi kurang aktif, kembali, subjek melakukan aktivitas waktu luang hanya dengan menonton televisi.

Scheduling activity yang telah dilakukan didapatkan penguat positif dari lingkungan. Penguat positif dari lingkungan tersebut berupa pujian atas hasil karya subjek yang didapat dari karyawan yayasan. Pujian tersebut menjadikan penguat positif sehingga perilaku subjek diulangi kembali. Salah satu jenis konsekuensi penguatannya adalah penguatan positif yang dimediasi oleh orang lain. Bila konsekuensi penguatan positif disampaikan oleh orang lain setelah perilaku sasaran, itu disebut penguatan positif sosial. Penguatan positif sosial mungkin melibatkan perhatian, akses terhadap aktivitas, atau bukti alami yang diberikan oleh orang lain (Miltenberger, 2012). Penguatan positif yang diberikan kepada subjek disetiap sesi, baik oleh terapis maupun karyawan atau orang-orang di sekitar, dapat meningkatkan motivasi subjek untuk melakukan aktivitas di waktu luang. Hal ini sesuai dengan penelitian dari (Lai, 2011).

Pemberian scheduling activity pada subjek, dapat mengurangi gejala negative yang dimiliki oleh subjek. Berkurangnya perilaku pasif serta meningkatnya motivasi untuk melakukan aktivitas merupakan perubahan yang didapat dari pemberian terapi tersebut.
Dari pemberian terapi tersebut, perilaku subjek berupa diam, tidak ada minat untuk beraktivitas berkurang sehingga subjek menjadi lebih aktif. Selain itu dari pemberian terapi dapat diketahui bahwa subjek juga dapat mengekspresikan persaannya terhadap aktivitas yang dilakukan. Sesuai dengan hasil penelitian bahwa gejala negative pada penderita skizofrenia menjadi berkurang dengan pemberian terapi scheduling activity. Subjek mendapatkan manfaat dari terapi yang diberikan seperti misalnya rasa senang dan puas ketika subjek dapat mneyelesaikan tugas dan mendapatkan penghargaan dari orang lain (Dogra et al., 2009).

\section{Simpulan}

Berdasarkan hasil intervensi yang telah dilakukan, scheduling activity dapat menigkatkan motivasi subjek untuk beraktivitas pada waktu luang. Namun penerapan intervensi tersebut memerlukan dukungan dari lingkungan sekitar serta pengawasan yang cukup intens. Subjek dapat memiliki inisiatif untuk beraktivitas di waktu luang.

\section{Referensi}

American Psychiatric Association. (2013). Diagnostic and statistical manual of mental disorders fifth edition. American Psychiatric Association.

Alwisol. (2011). Psikologi kepribadian edisi revisi. UMM Press.

Davison, Gerald C. (2006). Psikologi abnormal. PT. Raja Grafindo

Dogra, M., Rana, A., Das, K., \& Avasthi, A. (2009). An exploratory study on the effect of "activity scheduling" on the negative symptoms of patients with schizophrenia in psychiatry ward, nehru hospital, PGIMER, chandigarh. Nursing and Midwifery Research Journal, 5 (2), 107-115. https://doi.org/10.33698/nrf0098

Lai, E. R. (2011). Motivation: A literature review research. Pearson's Research Reports 43. https://doi.org/10.2307/ 3069464

Miltenberger, R. G. (2012). Behavior modification: Principles and procedures. Cengage Learning.

Nevid, J.S., Rathus, S.A. \& Greene, B. (2005). Psikologi abnormal edisi kelima, jilid 2. Penerbit Erlangga.

Wenzel, A., Brown, G. K., \& Karlin, B. E. (2011). Cognitive behavioral therapy for depression in veterans and military servicemembers: therapist manual. U.S. Department of Veterans Affairs

Winterwood, C., Beck, T. A., \& Gruener, D. (2003). Cognitive therapy with chronic pain patients. Springer Publishing, Inc. 